\title{
İngiliz Dili Eğitimi Anabilim Dalı Öğrencilerinin Görsel Okuryazarlık Düzeylerinin Analizi
}

DOI: $10.26466 /$ opus. 922770

\author{
* \\ Müfit Șenel * \\ * Dr. Öğr. Üyesi, Ondokuz Mayıs Üniversitesi, Eğitim Fakültesi, Samsun/Türkiye \\ E-Posta: msenel@omu.edu.tr \\ ORCID: 0000-0002-6982-0870
}

\section{Öz}

Görsel mesajlara anlam katma ve benzeri biçimde mesaj oluşturma becerisi olarak tanımlanabilen görsel okuryazarlık olgusu, aynı zamanda öğrenme ve öğretme sürecinin niteliğinin ve kalitesinin artırılmasında da önemli bir yer tutmaktadır. Görsel öğelere yabancı dil eğitimi ile ilgili çoğu beceride rastlanıldığı gerçeğgi herkes tarafindan bilinmektedir. Örneğ in, resimler, çizimler, kavram haritaları ve tablolar gibi görsel materyaller yabancı dil öğrenme ve öğretme süreçlerinin bir parçası olarak hemen hemen her ortamda ve kaynakta kullanılmaktadır. Bu yüzden öğrencilerin görsel okuryazarlık becerilerinin geliştirilmesi onların yabancı dil başarıları açısından önemli bir konudur. Bu araştırmanın amacı, 20192020 bahar döneminde, bir devlet üniversitesinin Eğitim Fakültesi İngiliz Dili Ĕ̆itimi Anabilim Dalında öğrenim görmekte olan 3. ve 4. sinıf öğrencilerinin görsel okuryazarlık düzeylerini çeşitli değişkenler açısından incelemek ve değerlendirmektir. Veri toplama aracı olarak "Görsel Okuryazarlık Yeterlikleri Ölçeği" kullanılmıştır. Elde edilen verilerin analizinde nicel analiz yöntemi kullanılmıştır. Araştırmanın sonuçlarına göre, öğrencilerin görsel okuryazarlık düzeyleri ile ilgili ortalama puanları yüksek düzeyde çıkmıştır. Ayrıca, çalışmada yer alan değişkenler açısından istatistiksel olarak anlamlı bir farklilık gözlenmemiştir.

Anahtar Kelimeler: İngiliz Dili Eğitimi, görsel okuryazarlık, dil öğretimi, yabancı dil. 


\title{
Determination of the Visual Literacy Levels of Students at the Department of English Language Teaching
}

\begin{abstract}
The phenomenon of visual literacy, which can be defined as the ability to produce and create meaningful messages has an important place in improving the quality and quantity of the learning and teaching process. The fact that visual elements are found in most skills related to foreign language education is known by everyone. For example, visual materials such as pictures, drawings, concept maps and tables are used in almost any environment and source as a part of the foreign language learning and teaching processes. Therefore, to improve students' visual literacy skills is an important subject for their foreign language achievements. The aim of this research is to examine and evaluate the visual literacy levels of $3 r d$ and 4th grade students majoring at the department of English Language Teaching at the Faculty of Education of a state university in 2019-2020 spring semester in terms of various variables. "Visual Literacy Levels Scale" was used as a data collection tool. Quantitative analysis method was used to evaluate the data obtained. According to the results of the study, the average scores of the students regarding their visual literacy levels were high. In addition, no statistically significant difference was observed in terms of the variables included in the study.
\end{abstract}

Keywords: English Language Teaching, visual literacy, language teaching, foreign language. 


\section{Giriş}

Son zamanlarda bilimsel ve teknolojik alanlarda ortaya çıkan hızlı gelişmeler insanların özelliklerini, yaşam tarzlarını, iletişim alışkanlıklarını ve hatta toplumların değerlerini etkilemeye ve değiştirmeye başlamıştır. Buna bağlı olarak, okuryazarlık kavramı genişleyerek farklı bir boyuta taşınmış, kısacası sadece okuma-yazma ile sınırlı kalmayıp, görselliğe ve görsel bilgiye de dayalı olmaya başlamıştır. İlk kez 1960'lı yıllarda ortaya atılmış olan görsel okuryazarlık kavramı, ileri yıllarda bireyin öğrenme ve öğretme süreçlerinde önemli bir faktör oluşturacağının habercisi olmuştur (Avgerinou and Ericson, 1997). Günümüzde de hem bir kavram hem de eğitsel bir olgu haline dönüşmüştür (Akyol, 2006). Moline'e (2012) göre ise görsel okuryazarlık bir yaşam belirtisidir. Petterson (2012), araştırmacıların görsel okuryazarlık konusunu inceledikleri çalışmaları araştırılmış ve 75 farklı alan belirlemiştir. Bunların içinde eğitim teknolojisi, öğrenme ve öğretmen yetiştirme alanları da yer almaktadır.

Alanyazında görsel okuryazarlıkla ilgili çok sayıda açıklama ve tanım bulmak mümkündür. Bunlardan biri, Heinich, Molenda ve Russel tarafından 1989 'da ortaya atılmış olan ve görsel okuryazarlığı, "görsel mesajlara anlam kazandırma ve benzer biçimde mesaj oluşturma" şeklindeki açılamalarıdır (s.77-79). Bir başka tanımda ise, Wileman (1993) görsel okuryazarlığ ' 'grafiksel ve resimsel olarak verilen bilgiyi okuyabilme ve anlayabilme' olarak ifade etmektedir. Petterson (1993) ise görsel okuryazarlığ1, bir süreç olarak tanımlamaktadır. Bu süreç, aynı zamanda, "bilgi, davranış ve dikkate değer yeteneklerin öğrenilip-öğretilebildiği ve değişik görsel biçimlerde iletişim becerilerini arttırmaya yönelik bir süreç" olarak da ifade edilmiştir (s.135). Bu tanımdan da anlaşılacağı gibi, "görsel okuryazarlık" kavramı, öğrenme-öğretme faaliyetleri ile daha geniş bir kavram niteliği kazanmıştır. Ayrıca görsel okuryazarlık, görsellerdeki gerekli bilgileri ayırt etme, güvenli bir şekilde seyahat etme ve hayatı güvenli bir şekilde devam ettirebilme gibi günlük hayatta karşılaşabileceğimiz farklı durumlarda da kişilere yarar sağlayacaktır (İşler, 2002). Yeh'e (2008) göre ise görsel okuryazarlık görsel mesajları doğru bir şekilde anlamak, yorumlamak, analiz edebilmek ve yaratmak için gerekli olan bilgi ve yetenektir. Başka bir ifadeyle, görsel okuryazarlık resim, grafik, çizim, sembol, 
şekil, renk gibi görsellerle, doğa ile sosyal olayları okuma, anlama, yorumlama ve zihinde yapılandırma süreci olarak da yorumlanmaktadır (Güneş, 2016; Çam, 2006).

Görsel okuryazarlığ 1 gelişmiş olan kişi, olayların, nesnelerin, sembollerin, doğal ya da yapay şeylerin ayrımını yapabilmekte ve onları yorumlayabilmektedir. "Görsel okuryazarlık yeterliği, bireyin sahip olduğu diğer becerileriyle etkileşim içinde olabilmektedir" (Bangir, 2008, s.80). Çünkü görsel imgelerin insanların iletişimde önemli bir yer tutması, bu imgeleri bireysel ya da toplumsal iletişimin vazgeçilmez parçaları haline getirmiştir. Dahası, bu imgeler hem öğrencilere hem de öğretmenlere her türlü bilgiyi ve kavramı kolayca hatırlayabilme imkanı sağlamakta olup, öğrenme ortamları için fayda unsuru olmaktadırlar. Ayrıca, eğitim sürecinde görsel okuryazarlık, bireyin görsel mesaj oluşturma ve yorumlama yeteneklerini zenginleştiren, görsel imgeleri kullanarak okuma ve yazma becerilerinin gelişimini sağlayan yeni eğitim programlarıyla mümkün olacaktır (Zeren ve Arslan, 2009).

Pettersson'a (1993) göre, çocuklar için görsel bilgi sözel bilgiden daha önemlidir. Ayrıca, görerek öğrenme sadece çocukların değil, aynı zamanda pek çok kişi tarafından da tercih edilen bir öğrenme biçimidir çünkü dinleme yoluyla sadece \%10 oranında bir öğrenme sağlanırken, görerek öğrenmede bu oran \%80'e çıkmaktadır. Dahası, duyduklarımızın sadece $\% 20$ 'sini hatırlayabilirken, hem görüp hem duyduklarımızda bu oran \% 50'nin üstüne çıkmaktadır (Heinich vd., 1989). Dolayısıyla, görsel okuryazarlık becerisine sahip öğrencilerin derslerinde kendilerine sunulan görsellerin altında yatan mesajları daha iyi anlayabilecekleri düşünüldügüunden (Şahin vd., 2013), görselleri anlamak ve anlatmak için görselliğe yönelik bir okuryazarlık türüne ihtiyaç duyulmuştur (Göçer ve Tabak, 2013).

Bu alanda yapılan çalışmalar doğrultusunda, Duran (2013, s.37) ortaokul 7. sınıf öğrencilerinin 'görsel matematik okuryazarlığı' üzerine yapmış olduğu araştırmada, öğrencilerin çoğunun görsel matematik okuryazarl1ğını "şekil içeren soruları okuyabilmeye, kavrayabilmeye ve yorumlayabilmeye dayalı bir okuryazarlık" ve "görsel şekillere, sembollere ve bütününe hâkim olmaya dayalı bir okuryazarlık", olarak ifade ettikleri sonucuna varmıştır. Yine aynı düzey öğrencilerle yapılmış olan bir başka çalış- 
mada, 7. sınıf öğrencilerinin görsel okuryazarlık düzeyleri akademik başarıları açısından bir farklılık göstermezken, cinsiyet açısından anlamlı farklılık ortaya çıkmıştır (Özdemir ve Yıldız, 2015).

1999 yılında, Roth, Bowen ve McGinn tarafından yapılmış olan bir araştırma sonucuna göre, öğrencilerin ve aday öğretmenlerin öğretim araç ve gereçlerindeki grafikleri, çizimleri, tabloları, şekilleri, vb. yorumlamada zorlandıklarını ve hatta bazı görsel imgeleri okumak için herhangi bir çaba göstermediklerini ortaya koymuştur. Çalışmasında görsel okuryazarlık ile öğretim teknolojisi arasındaki ilişkiyi incelemiş olan Alpan (2008), görsel okuryazarlı̆̆ın, öğretim teknolojisinin nasıl etkili bir şekilde kullanılması gerektiğine yardımcı olduğunu ifade etmiştir. Uzun ve Çelik (2020) tarafından akademisyenlerin okuryazarlık algısındaki değişimlerini araştırmak amacıyla yürütülen çalışma sonucunda ise, akademisyenlerin bilgi okuryazarlığı ile görsel okuryazarlığı derslerinde daha çok tercih ettikleri belirlenmiştir. Coğrafya öğretmenlerinin öğrencilerde görsel okuryazarlık becerilerinin geliştirmesi hakkında yapılmış olan bir araştırmanın sonucunda, öğretmenlerin büyük bir bölümünün görsel okuryazarlığın gerekliliği hakkında hem fikir oldukları, fakat ders kitaplarının görsel okuryazarlık kazandırmada yetersiz kaldığı görüşüne sahip oldukları ortaya çıkmıştır (Kaya, 2011).

Alanyazında ayrıca, Arıkök (2001); Erdem (2006); Demirci (2010); Cengiz (2002); Akaroğlu ve Dereli (2012) tarafından okul öncesi gruplarla yapılan çalışmalar; Akçam (2006); Çam (2006) ve Akpınar'ın (2009), İlkokul düzeyindeki öğrencilerin 'okuma becerileri ve metinlerle anlam kurma' alanıyla ilgili gerçekleştirdiği çalışmalarla birlikte, yine Çam (2006); Balun (2008) ve Akpınar (2009) tarafından ilkokul düzeyinde görsel okuryazarlık konusunu Türkçe dersi ile ilişkilendiren çalışmalar yer almaktadır. $\mathrm{Bu}$ alanda yapılan araştırmaların çoğunun öğrencilerin görsel okuryazarlıklarının 'Matematik, Türkçe ve Öğretim Teknolojileri' alanları ile ilgili olduğu sonucuna varılmıştır. Örs ve Baş (2017), 2. sınıflardaki Türkçe dersi için 'görsel okuma ve görsel sunu' kazanımlarıyla ilişkili etkinlikler oluşturmuşlar ve bu etkinliklerin 2. sınıf öğrencilerinin görsel okuryazarlık gelişimine etkisini incelemişlerdir. Çalışma sonucunda, ilgili kazanımları geliştirmede, etkinliklerin çalışma grubu için faydalı olduğu sonucuna ulaşmışlardır. Yine benzer bir çalı̧̧ma, Türkçe eğitimi bölümü son sınıf öğrencilerinin görsel okuryazarlık yeterliklerinin öğrenim türlerine göre 
incelenmesi üzerine yapılmıştır (Erem ve Kırkkılıç, 2015). Elde edilen bulgular sonucunda, öğrencilerin görsel okuryazarlık düzeylerinin normal ve yeterli olduğu, ayrıca ikinci öğretim öğrencilerine göre de farklılık göstermediği görülmüştür.

Temizkan ve Ünlüoğlu (2017) ise, görsel materyallerle destekledikleri yazma çalışmasının, öğrencilerin yazma başarısı ve yazma becerisi ile ilgili görüşleri üzerindeki etkisini inceledikleri çalışma sonunda, görsel materyallerle desteklenen yazma etkinliklerinin öğrencilerin yazma başarılarını arttırdığı bulgusunu elde etmişlerdir. Harmanlanmış öğrenmenin, hizmet içi öğretmenlerin görsel okuryazarlıkları üzerindeki etkisini görmek için yapılmış olan bir başka araştırmada ise, 20 saatlik harmanlanmış öğrenme sonrasında, öğretmenlerin görsel okuryazarlık düzeylerinin geliştiği ortaya çıkmıştır (Huilcapi-Collantes vd., 2020). Görsel okuryazarl1ğın dil eğitimine ne tür katkı sağlayabileceğini irdeleyen bir çalışma sonucunda, görsel imgelerin öğretim sürecine dahil edilmesinin, öğrencilerin öğrenme düzeylerini artırmada önemli bir katkı sağladığı bulgusuna varilmıştır (Suryanto, 2014).

Bu bölümde bahsedilen çalışmaların büyük çoğunluğu, görsel okuryazarlığın genelde akademik başarı, gereklilik, görselleri yorumlayabilme, öğrenim türleri üzerine etkisi, okuma becerilerine katkısı, vb. değişkenler açısından sınırlandırılmıştır. Ayrıca, Türkiye'de İngilizce öğretmenliği bölümü öğrencilerinin görsel okuryazarlık düzeyleri üzerine yapılmış benzer bir çalışmaya da rastlanmamıştır. Felten'e (2008) göre, görsel okuryazarlık üniversite öğrencileri için doğal bir ortam olarak kabul edilmekle birlikte, kendiliğinden kazanılabilecek bir beceri değildir ve ayrıca planlı bir eğitim süreci gerektirmektedir (Braden, 1996). Bu bağlamda, özellikle eğitim fakültelerinin yabancı diller bölümlerinde okumakta olan öğretmen adayları için görsel okuryazarlık özelliğine sahip olmak son derece önemlidir çünkü yabancı dil öğretiminde görsel kullanımı, bu öğretimin en önemli unsurlarından biridir. Ayrıca, yabancı dil öğretmenlerinin görsel imgeleri öğretim sürecine dahil edebilmesi ve anlamlandırabilmesi için görsel okuryazarlığa sahip olmaları gerekmektedir. Görsellerle yapılan yabancı dil dersleri hem dersleri daha anlaşılır hale getirecek, hem de öğrencileri güdüleyerek derse katılımlarını daha etkin kılacaktır. Bu doğrultuda, MEB Talim Terbiye Kurulu Başkanlığı tarafından yayınlanmış 
olan “İlköğretim Kurumları (2.-8. sinfflar) İngilizce Dersi Öğretim Programı" (2018) ile “Ortaöğretim İngilizce Dersi (9.-12. sinıflar) Öğretim Programı" nda da önerilen materyallerin, kaynakların ve etkinliklerin (örneğin, rol yapma etkinliği, kısa ve sözlü sunumlar, bilgi tamamlama aktiviteleri, betimleyici metin yazma, drama, çizgi filmler, menüler, listeler, resimli sözlük, tablolar, haritalar, vb.) büyük ölçüde görsel okuryazarlık farkındalığını ön plana çıkarttığı görülmektedir (2018). Giriş bölümünde de ifade edildiği şekilde, Eğitim Fakülteleri İngilizce öğretmenliği bölümü öğrencilerinin görsel okuryazarlık düzeylerini araştıran herhangi bir çalışma olmaması bu alanda çalışma yapılması gerekliliğini ortaya koymaktadır. Sonuç olarak, bu çalışma İngilizce öğretmenliği bölümü adaylarının görsel okuryazarlık düzeylerini çeşitli değişkenler açısından ele aldığından, alanyazında İngilizce öğretmenliği bölümü öğrencilerinin görsel okuryazarlık düzeylerini araştırmaya yönelik benzer bir çalışma yapılmamış olduğundan, alana yapacağı katkı bakımından önem teşkil etmektedir.

\section{Araştırmanın Amacı}

Bu çalışmada, bir devlet üniversitesinin, İngiliz Dili Eğitimi Anabilim Dalı 3. ve 4. sınıf öğrencilerinin farklı değişkenler açısından görsel okuryazarlık düzeylerini araştırmak amacıyla aşağıdaki sorulara cevap aranmıştır: İngiliz Dili Eğitimi Anabilim Dalı öğrencilerinin, görsel okuryazarlık yeterlilikleri,

1. cinsiyetlerine,

2. öğrenim görmekte oldukları sınıflarına,

3. yaşlarına ve

4. mezun oldukları okullara göre anlamlı bir farklılık göstermekte midir?

Bu değişkenlerin seçilmesindeki amaçlar şu şekilde açıklanabilir. Cinsiyet, yaş ve bulundukları sınıf değişkeninin ele alınmış olma sebebi, katılımcıların bilişsel ve kavramsal açıdan görsel okuryazarlık konusunda belirgin bir farka sahip olup olmadıkların belirlemeye; mezun oldukları okullar değişkeni ise farklı öğretim programları uygulayan ortaöğretim kurumlarından gelmiş olan katılımcıların, görsel okuryazarlık düzeyle- 
rinde görmüş oldukları farklı programların bir etkisi olup olmadığını belirlemeye çalışmaktadır. Dolayısıyla, bu çalışmanın sonuçları Eğitim Fakülteleri İngiliz Dili Eğitimi bölümündeki öğrencilerin görsel okuryazarlık düzeylerinin belirlenmesi, bundan sonra yapılacak olan öğretim programları ve düzenlemelere yardımcı olabilecek fikirler sunabilir ve yabancı dil eğitiminde görsel okuryazarlığa ne denli ihtiyaç olduğu konusunda alana katkı sağlayabilir.

\section{Yöntem}

\section{Araştırma Modeli}

Betimsel nitelikte bir çalışma olup, nicel araştırma modeli kullanılmıştır. Nicel araştırmalar, sayısal olarak ifade edilebilen verilerin istatistiksel çözümlemeleri olup, sosyal veriler arasındaki neden-sonuç ilişkilerini ortaya koymayı hedefleyen araştırmalardır. Dahası, araştırmacı tarafından önceden ortaya atılmış olan hipotezleri test etmek için belli örnek ve örneklemlerden veriler toplayan ve bu verileri istatistiksel olarak çözümlemeyi hedefleyen araştırmalardır (http://www.bingol.edu.tr/media/204988/sayt-bolum8 Sosyolojide-Nicel-ve-Nitel Arastirma-Yontemleri.pdf ). Nicel araştırmalar, genel sonuçlar elde etmeye, farklı gruplar arasında karşılaştırma yapabilmeye, kuramların doğruluk dereceleri denemeye ve belli yapılar içindeki ilişkilerin incelenmesine imkan sağlar (Büyüköztürk vd., 2010). Ayrıca, "belli değişkenler arasındaki sebep-sonuç ilişkilerini tespit etmek ve sonuçlarını kıyaslamak için de nicel araştırma yöntemleri kullanılmaktadır ve elde edilen bulguların sayısal değerlerle ifade edilerek ölçülebilir hale getirilmesi ve araştırmanın hipoteze dayandirılarak bu hipotezlerin test edilmesidir" (Ekiz, 2003, s.93)

\section{Evren ve Örneklem}

Araştırmanın evrenini 2019-2020 bahar döneminde bir devlet üniversitesinin Eğitim Fakültesi oluşturmakta olup, örneklemini de İngiliz Dili Eğitimi Anabilim Dalında öğrenim görmekte olan 3. (\%44.7) ve 4. (\%55.3) s1nıf öğrencileri oluşturmaktadır. Bu sınıflardaki öğrencilerin çalışmada yer almış olması, bulundukları sınıflardaki derslerinde görsel materyallerin 
daha fazla kullanılmakta olması ve görsel okuma ve anlama açısından belli bir yetiye sahip olmuş oldukları beklentisi sonucudur. Bu öğrencilerin hiçbirisi daha önceden görsel okuryazarlıkla ilgili herhangi bir eğitim almamıştır. Gönüllülük esasına göre çalışmaya 123 öğrenci katılmış olup, bunların 98'i (\%79.7) kız, 25'i (\%20.3) erkektir. Bu öğrencilerin 55'ini (13 erkek, 42 kız) 3. sınıf, 68'sini de (12 erkek, 56 kız) 4 . sınıf öğrencileri oluşturmaktadır. 52 (\%42.3) öğrenci 19-21, 71 (\%57.7) öğrenci ise 22-24 yaş aralığındadır. Katılımcların mezun oldukları liselere göre dağılımı ise şöyledir: Anadolu Lisesi 62 (\%50.4), Anadolu İmam Hatip Lisesi 39 (\%31.7) ve Anadolu Öğretmen Lisesi 22 (\%17.9).

\section{Veri Toplama Aracı}

Veri toplama aracı olarak, Kiper, Arslan, Kıyıcı ve Akgün (2012) tarafından geliştirilmiş olan "Görsel Okuryazarlık Yeterlikleri Ölçeği” kullanılmıştır. "Görsel Okuryazarlık Yeterlikleri Ölçeği" nin kodlaması: (1) Kesinlikle yapamam, (2) Yapamam, (3) Az çok yaparım, (4) Yaparım ve (5) Kolaylıkla yaparım, şeklinde olup, beşli Likert tipi bir ölçektir. Güvenirlik katsayısı 0.94 olarak verilmiştir. Ölçek, (1-7) 'ofis yazılımları kullanarak görselliğe önem verebilme', (8-11) 'basılı görsel materyalleri tanımlayabilme', (12-16) 'görsel yorumlayabilme', (17-21) 'günlük hayatta karşılaş1lan görsel mesajları ayırt edebilme', (22-26) 'araçlar kullanarak görsel üretebilme' ve (27-29) 'görsellerdeki mesajları algılayabilme' şeklinde altı alt boyuttan oluşmaktadır ve bu alt boyutlar için güvenirlik katsayıları 0.89, $0.83,0.86,0.78,0.77,0.68$ olarak hesaplanmıştır. Ölçek aynı zamanda tüm alt boyutlar için de güvenilirdir (Kalayc1, 2014).

\section{Veri Toplama Yöntemi}

Gönüllülük esasına göre çalışmaya katılan öğrencilerden, İnternet üzerinden (Google.docs ${ }^{\circledR}$ ) paylaşımı yapılan "Görsel Okuryazarlık Yeterlikleri Ölçeği" ni kendilerine göre en uygun seçeneği işaretleyerek doldurmaları istenmiştir. Sonuçların sadece bu çalışma için kullanılacağı belirtilmiş olup, başka hiçbir yerde yayınlanmayacağı konusunda kendilerine güvence verilmiştir. Ölçek toplam 187 öğrenciye gönderilmiştir ancak 123 öğrenciden cevap alınabilmiştir. 


\section{Verilerin Analizi}

Çalışmada elde edilen verilerin tümü SPSS 25 programı ile analiz edilmiştir. Çalışmada kullanılacak analizleri belirlemek için, öncelikle elde edilen verilerin normal dağılıma uygun olup olmadığı sonucu araştırılmış ve verilerin normal dağılıma uygun olduğu tespit edilmiştir ( $p$ >.05). Normal dağılım sonucuna bağlı olarak parametrik analiz yöntemlerinin kullanılması gerektiği sonucuna varılmıştır. Bu parametrik analizler, katılımcıların görsel okuryazarlık yeterliklerinin cinsiyet, yaş, sınıf ve mezun oldukları okul türlerine göre farklılaşıp farklılaşmadığını tespit etmek için kullanılmıştır. Yapılacak analizler, 'Frekans analizi', 'Bağımsız Gruplar t-Testi' ve 'Tek Yönlü Varyans Analizi' olarak belirlenmiştir. Katılımcıların ölçeğe vermiş oldukları cevaplar, 1-5 değerleri aralığında puanlandırılmıştır. Ölçeğin toplam ve alt boyutlarından elde edilen ortalama değerlerinin belirlenmesi için ise, katılımcların görsel okuryazarlık düzeylerini gösteren değerlendirme puan aralıkları belirlenmiştir. Bu değerlendirme puan aralıkları, 1.00-1.80 arası "Kesinlikle Yapamam" (Çok Düşük); 1.81-2.60 arası "Yapamam" (Düşük); 2.61-3.41 arası "Az Çok Yaparım" (Orta Düzey); 3.41-4.20 arası "Yaparım" (Yüksek) ve 4.21-5.00 arası da "Kolaylıkla Yaparım" (Çok Yüksek) şeklindedir.

\section{Bulgular}

Bu bölümde araştırmaya katılan öğrencilerin görsel okuryazarlık düzeylerinin incelendiği analizlere ve bulgulara yer verilmiştir. Öncelikli olarak katılımcıların ölçekte yer alan ifadelere verdikleri cevapların genel bir değerlendirilmesi tablolar şeklinde sunulmuştur.

Katılımcıların "Görsel Okuryazarlık Yeterlikleri"ni belirlemeye yönelik kullanılan ölçme aracının genelinden ve her bir alt boyutundan aldıkları puanlarla ilgili değerlerin tamamı toplu olarak Tablo 1'de verilmiştir. 
Tablo 1. Görsel Okuryazarlık Yeterlik Ölçeğinden alınan puanlar

\begin{tabular}{lllll}
\hline & $\overline{\mathbf{x}}$ & min. & maks. & ss \\
\hline Ofis yazılımları kullanarak görselliğe önem verebilme & 4.23 & 3.86 & 4.57 & .216 \\
Basıllı görsel materyalleri tanımlayabilme & 3.29 & 3.00 & 3.75 & .022 \\
Görsel yorumlayabilme & 4.39 & 4.20 & 4.60 & .011 \\
Günlük hayatta karşılaşılan görsel mesajları ayırt edebilme & 3.97 & 3.40 & 4.40 & .035 \\
Araçlar kullanarak görsel üretebilme & 2.72 & 2.40 & 3.40 & .028 \\
Görsellerdeki mesajları algılayabilme & 4.27 & 4.00 & 4.67 & .023 \\
Görsel Okuryazarlık Yeterlik Genel Değerlendirme Puanı & 3.81 & 3.47 & 4.23 & .055 \\
\hline
\end{tabular}

Tablo 1 incelendiğinde araştırmada yer alan katılımcıların görsel okuryazarlık yeterlik ölçeği toplam puanın ortalamasının $(\bar{x}=3.81)$ olduğu görülmektedir. Değerlendirme kapsamında 3.41-4.20 aralığ "Yaparım" ifadesine denk gelmektedir ve bu sonuca göre katılımciların görsel okuryazarlık yeterliğinin yüksek olduğu ifade edilebilir. Ölçek alt boyutlarına ait ortalama değerlere bakıldığında da, en yüksek puanın $(\bar{x}=$ 4.67) "Görsellerdeki Mesajlar Algılayabilme" alt boyutuna ve en düşük puanın da ( $\bar{x}=2.40)$ "Araçlar Kullanarak Görsel Üretebilme" alt boyutuna ait olduğu görülmektedir. Tüm alt boyutların ortalamaları ise $\overline{x=2.72}$ ile $\overline{x=}$ 4.39 arasında yer almaktadır. Bu değerler ışığında, katılımcıların beşinci alt boyuttaki görsel okuryazarlık yeterlikleri orta düzeyde olmasına rağmen, diğer tüm öğrencilerin tüm alt boyutlar için görsel okuryazarlık yeterliklerinin iyi düzeyde olduğu sonucuna varılabilir.

Birinci Araştırma Sorusuna Ait Bulgular: Araştırmanın ilk sorusu, "İngiliz Dili Eğitimi Anabilim Dalı öğrencilerinin, görsel okuryazarlık yeterlikleri cinsiyetlerine göre farklılık göstermekte midir?" şeklindedir. Katılımcıların cinsiyetlerine göre görsel okuryazarlık yeterliliklerinin ne düzeyde olduğunu belirlemek amacıyla ölçek ve alt boyut (AB) puanlarına ilişkin ortalama ve standart sapma değerleri Tablo 2'de verilmiştir.

Tablo 2' de erkek ( $\overline{\mathrm{X}}=3.80$ ) ve kız ( $\overline{\mathrm{X}}=4.07$ ) katılımcıların görsel okuryazarlık ölçeği toplam puanları arasında belirgin bir fark olmadığ 1 görülmektedir. Bağımsız Gruplar t-testi sonucuna bakıldığında, erkek ve kızların ortalamaları arasında da istatistiksel olarak anlamlı bir fark olmadığı ortaya çıkmıştır [ $t(121)=.353$, p>.05]. Katılımcıların cinsiyete göre görsel okuryazarlık alt boyut puanları arasında anlamlı bir farkın olup olma- 
dığına ilişkin elde edilen veriler kapsamında, katılımcılar açısından istatistiksel olarak anlamlı bir farklılık ortaya çıkmamıştır (AB-1 [t (121) =.703, $\mathrm{p}>$.05]; AB-2 [t (121) =.014, p >.05]; AB-3 [t (121) =.075, p >.05]; AB-4 [t $(121)=.029, \mathrm{p}>.05] ;$ AB-5 [ $\mathrm{t}(121)=.458, \mathrm{p}>.05] ; \mathrm{AB}-6$ [ $\mathrm{t}(121)=.839, \mathrm{p}>.05]$ ). Ancak, Görsel Okuryazarlık Ölçeği'nin beşinci alt boyutu olan "Araçlar Kullanarak Görsel Üretebilme" konusunda, elde edilen verilerin aritmetik ortalamasına göre, kız katılımcılar lehine bir fark gözlemlendiği söylenebilir $(\bar{x}=4.28)$.

Tablo 2. Görsel Okuryazarlık Yeterliği Toplam ve Alt Boyut Puanlarnnn Cinsiyete Göre t-Testi Sonuçlarn

\begin{tabular}{|c|c|c|c|c|c|c|c|}
\hline $\begin{array}{l}\text { Ölçek Alt } \\
\text { Boyutları }\end{array}$ & Cinsiyet & $N$ & $\overline{\mathrm{X}}$ & $S$ & $s d$ & $t$ & $p$ \\
\hline & $\mathrm{K}_{1 \mathrm{Z}}$ & 98 & 4.25 & .21 & & & \\
\hline \multirow[t]{2}{*}{$A B-1$} & Erkek & 25 & 4.22 & .22 & 121 &.-703 & .483 \\
\hline & $\mathrm{K}_{1 \mathrm{Z}}$ & 98 & 3.29 & .25 & & & \\
\hline \multirow[t]{2}{*}{$A B-2$} & Erkek & 25 & 3.29 & .24 & 121 & .014 & .988 \\
\hline & $\mathrm{K}_{1 \mathrm{Z}}$ & 98 & 4.39 & .12 & & & \\
\hline \multirow[t]{2}{*}{$A B-3$} & Erkek & 25 & 4.38 & .13 & 121 & --075 & .940 \\
\hline & $\mathrm{K}_{1 Z}$ & 98 & 3.97 & .38 & & & \\
\hline \multirow[t]{2}{*}{$A B-4$} & Erkek & 25 & 3.97 & .41 & 121 & -029 & .977 \\
\hline & $\mathrm{K}_{1 \mathrm{Z}}$ & 98 & 4.28 & .32 & & & \\
\hline \multirow[t]{2}{*}{$A B-5$} & Erkek & 25 & 2.69 & .28 & 121 & .458 & .648 \\
\hline & $\mathrm{K}_{1 Z}$ & 98 & 4.28 & .26 & & & \\
\hline$A B-6$ & Erkek & 25 & 4.24 & .24 & 121 & .839 & .403 \\
\hline Ölçek Ort. & $\mathrm{K}_{1 \mathrm{Z}}$ & 98 & 4.07 & .26 & & & \\
\hline Toplam & Erkek & 25 & 3.80 & .25 & 121 & .353 & .739 \\
\hline
\end{tabular}

İkinci Araştırma Sorusuna Ait Bulgular: “İngiliz Dili Eğitimi Anabilim Dalı öğrencilerinin görsel okuryazarlı yeterlikleri öğrenim görmekte oldukları sinıflara göre farklılık göstermekte midir?" çalışmanın ikinci araştırma sorusunu oluşturmaktadır. Katılımcıların bu soruya yönelik cevaplarının analizi Tablo 3' de verilmiştir.

Tablo 3'te belirtildiği gibi, gerek ölçek toplam puanı (3. Sınıf $\overline{\mathrm{X}}=3.79,4$. Sınıf $\overline{\mathrm{x}}=3.82$ ) ve gerekse de tüm alt boyutlar için elde edilmiş olan aritmetik ortalamalara göre katılımcıların öğrenim görmekte oldukları sınıflara göre aralarında istatistiksel olarak belirgin bir fark gözlemlenmemiştir. $(\mathrm{AB}-1$ [ $\mathrm{t}(121)=.174, \mathrm{p}>.05] ; \mathrm{AB}-2$ [t $(121)=.1078, \mathrm{p}>.05] ;$ AB-3 [t (121) $=1.198, \mathrm{p}>.05] ; \mathrm{AB}-4$ [t (121) =.383, $\mathrm{p}>.05$ ]; AB-5 [t (121) =.1.110, $\mathrm{p}>.05$ ]; 
AB-6 [t (121) =1.434, p >.05] ). Katılımciların farklı sınıflarda olması, onların görselleri yorumlamada bilişsel ve kavramsal açıdan birbirlerinden çok farklı olmadıkları sonucunu ortaya koymuştur.

Tablo 3. Görsel Okuryazarlık Yeterliği Toplam ve Alt Boyut Puanlarnın Sınıflara Göre t-Testi Sonuçlart

\begin{tabular}{|c|c|c|c|c|c|c|c|}
\hline $\begin{array}{l}\text { Ölçek Alt } \\
\text { Boyutları }\end{array}$ & Sinif & $N$ & $\overline{\mathrm{X}}$ & $S$ & $S d$ & $t$ & $p$ \\
\hline & 3.sinif & 55 & 4.23 & .220 & & & \\
\hline \multirow[t]{2}{*}{$A B-1$} & 4.sinif & 68 & 4.22 & .214 & 121 & .174 & .862 \\
\hline & 3.sinif & 55 & 3.26 & .247 & & & \\
\hline \multirow[t]{2}{*}{$A B-2$} & 4.sinif & 68 & 3.31 & .253 & 121 & -1.078 & .283 \\
\hline & 3.sinif & 55 & 4.37 & .133 & & & \\
\hline \multirow[t]{2}{*}{$A B-3$} & 4.sinif & 68 & 4.40 & .126 & 121 & -1.198 & .233 \\
\hline & 3.sinif & 55 & 3.98 & .404 & & & \\
\hline \multirow[t]{2}{*}{$A B-4$} & 4.sinif & 68 & 3.96 & .380 & 121 & .383 & .703 \\
\hline & 3.sinif & 55 & 2.68 & .292 & & & \\
\hline \multirow[t]{2}{*}{$A B-5$} & 4.sinif & 68 & 2.75 & .333 & 121 & -1.110 & .269 \\
\hline & 3.sinif & 55 & 4.24 & .235 & & & \\
\hline$A B-6$ & 4.sinif & 68 & 4.30 & .278 & 121 & -1.434 & . 154 \\
\hline Ölçek Ort. & 3.sinif & 55 & 3.79 & .255 & & & \\
\hline Toplam & 4.sinıf & 68 & 3.82 & .264 & 121 & .896 & .417 \\
\hline
\end{tabular}

Üçüncü Araştırma Sorusuna Ait Bulgular:Çalışmanın üçüncü araştırma sorusu "İngiliz Dili Eğitimi Anabilim Dalı öğrencilerinin görsel okuryazarlık yeterlikleri yaşlarına göre farklılık göstermekte midir?" şeklinde sorulmuştur. Tablo 4'de sunulan verilerin analizi ışığında varılan sonuçlar aşağıda verilmiştir.

Ölçek toplam puan aritmetik ortalamasına göre 19-21 yaş arası katılımcı için elde edilen aritmetik ortalama ( $\bar{X}=380$ ) ile 22-24 yaş grubu için elde edilen aritmetik ortalaması ( $\overline{\mathrm{X}}=4.07$ ) arasında istatistiksel olarak anlamlı bir fark ortaya çıkmamıştır ( $\mathrm{p}>$.05). Ölçek alt boyutları içinde yaş grupları arasında istatistiksel olarak anlamlı fark bulunamamıştır (AB-1 [t $(121)=.155, \mathrm{p}>.05] ; \mathrm{AB}-2$ [t (121) =.439, p >.05]; AB-3 [t (121) =.677, p >.05]; AB-4 [t (121) =.071, p >.05]; AB-5 [t (121) =.889, p >.05]; AB-6 [t (121)=1.337, $\mathrm{p}>$.05]). Ancak birinci araştırma sorusunun verilerine benzer şekilde, Görsel Okuryazarlık Ölçeği'nin beşinci alt boyutu olan "Araçlar Kullanarak Görsel Üretebilme" konusunda elde edilen verilerin aritmetik ortalamasına göre, kız katılımcılar lehine bir fark gözlemlenmiştir ( $\overline{\mathrm{X}}=4.28)$. 
Tablo 4. Görsel Okuryazarlık Yeterliği Toplam ve Alt Boyut Puanlarııın Yaşa Göre t-Testi Sonuçları

\begin{tabular}{|c|c|c|c|c|c|c|c|}
\hline $\begin{array}{l}\text { Ölçek Alt } \\
\text { Boyutları }\end{array}$ & Yaş & $N$ & $\overline{\mathrm{X}}$ & $S$ & $s d$ & $t$ & $p$ \\
\hline & $19-21$ & 52 & 4.23 & .217 & & & \\
\hline \multirow[t]{2}{*}{$A B-1$} & $22-24$ & 71 & 4.22 & .216 & 121 & .155 & .483 \\
\hline & $19-21$ & 52 & 3.27 & . 265 & & & \\
\hline \multirow[t]{2}{*}{$A B-2$} & $22-24$ & 71 & 3.29 & .241 & 121 & -.439 & .988 \\
\hline & $19-21$ & 52 & 4.38 & .138 & & & \\
\hline \multirow[t]{2}{*}{$A B-3$} & $22-24$ & 71 & 4.39 & .124 & 121 & -.677 & .940 \\
\hline & $19-21$ & 52 & 3.97 & .405 & & & \\
\hline \multirow[t]{2}{*}{$A B-4$} & $22-24$ & 71 & 3.97 & .381 & 121 & .071 & .977 \\
\hline & $19-21$ & 52 & 2.69 & .302 & & & \\
\hline \multirow[t]{2}{*}{$A B-5$} & $22-24$ & 71 & 4.28 & .326 & 121 & -.889 & .648 \\
\hline & $19-21$ & 52 & 4.28 & .229 & & & \\
\hline$A B-6$ & $22-24$ & 71 & 4.24 & .280 & 121 & -1.337 & .403 \\
\hline Ölçek Ort. & $19-21$ & 52 & 3,80 & .26 & & & \\
\hline Toplam & $22-24$ & 71 & 4.07 & .25 & 121 & .594 & .739 \\
\hline
\end{tabular}

Dördüncü Araştırma Sorusuna Ait Bulgular: Çalışmanın dördüncü araştırma sorusu olan "İngiliz Dili Eğitimi Anabilim Dalı öğrencilerinin görsel okuryazarlı yeterlikleri mezun oldukları okullara göre farklılı göstermekte midir?" için veri analizi Tek Yönlü Varyans Analizi (ANOVA) kullanılarak elde edilmiştir.

Tablo 5' deki veriler doğrultusunda, ölçek toplam aritmetik ortalama puanına göre ( $\overline{\mathrm{X}}=3.81$ ) katılımcların mezun oldukları liseler düzeyinde yüksek seviyede görsel okuryazarlık sahibi oldukları sonucuna varılmaktadır ( $\overline{\mathrm{X}}=3.41-4.20$ arası "Yaparım" -Yüksek Düzey). Tablo 5'te görüldüğü üzere, ölçek alt boyut puan ortalamalarının okul türü değişkenine göre aritmetik ortalamalarının anlamlı bir farklılık gösterip göstermediğini belirlemek amacıyla yapılan tek yönlü varyans analizi sonucunda, tüm ölçek alt boyutları açısından da lise türü değişkenine göre, grupların aritmetik ortalamaları arasında istatistiksel olarak anlamlı bir fark bulunamamıştır (AB-1 [F(.852; .429), p > .05]; AB-2 [F(.015; .986), p > .05]; AB-3 [F(.512; .601), $\mathrm{p}>$.05]; AB-4 [F(.306; .737), $\mathrm{p}>$.05]; AB-5 [F(2.882; .060), $\mathrm{p}>.05] ; \mathrm{AB}-6$ $[\mathrm{F}(.654 ; .522), \mathrm{p}>.05])$. Dolayısıla, katılımciların farklı programlardan gelmiş olmaları, görsel okuryazarlık düzeylerinde belirgin bir fark yaratmamiştır. 
Tablo 5. Görsel Okuryazarlık Yeterliği Toplam ve Alt Boyut Puanlarının Mezun Olunan Okul Türüne Göre Tek Yönlü Varyans Analizi Sonuçları

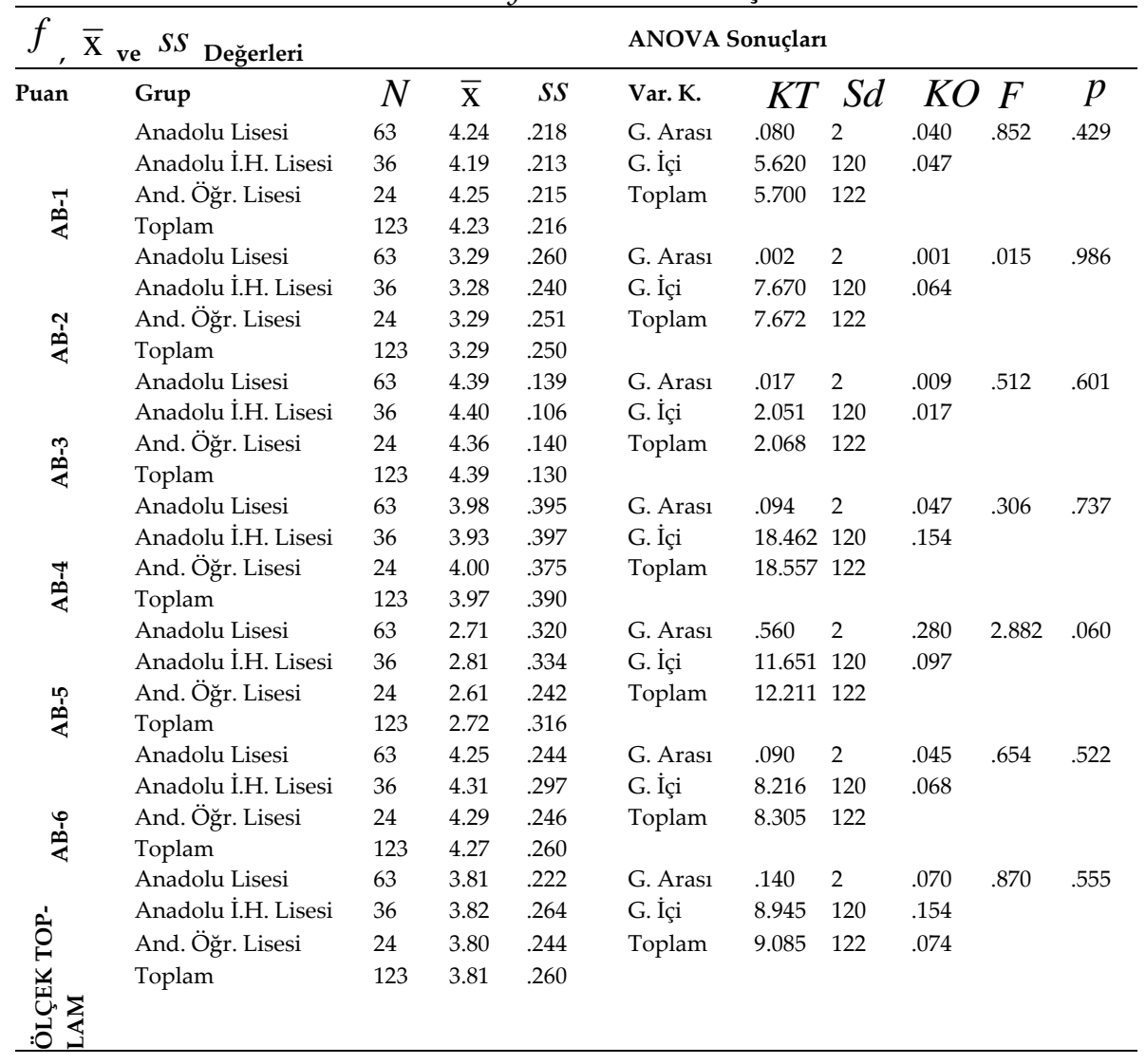

\section{Tartışma, Sonuç ve Öneriler}

Araştırmanın sonucuna göre, çalışmaya katılan İngiliz Dili Eğitimi Anabilim Dalı 3. ve 4. sınıf öğrencilerinin görsel okuryazarlık düzeylerinin belirlenmesine yönelik ölçekte yer alan maddelere vermiş oldukları cevapların ortalamalarına bakıldığında, katılımcıların yüksek seviyede görsel okuryazarlık düzeyine sahip oldukları sonucu elde edilmiştir. Kocaarslan ve Çeliktürk'ün (2013) yapmış olduğu çalışmanın sonuçlarına göre, Eğitim Fakültesi öğrencilerinin genel olarak görsel okuryazarlık yeterlik düzeyleri yüksektir ve bu çalışmada elde edilen sonuçlarla 
uyuşmaktadır. Aynı şekilde, iki farklı devlet üniversitesindeki öğrencilerle yapılmış olan çalışmadan elde edilen veriler, çalışmaya katılan öğrencilerin görsel okuryazarlık düzeylerinin oldukça yüksek olduğunu ortaya koymuştur ki bu bulgularla mevcut çalışmanın bulguları denktir (Kiper vd., 2014). Ayrıca, özel yetenekli öğrenci ve akranlarının, "Görsel Okuryazarlık Yeterlik Ölçeği"nden aldıkları toplam puanlara göre, öğrencilerin yüksek düzeyde görsel okuryazar oldukları sonucuna ulaşılmıştır ki bu sonuçların burada sunulan çalışmanın sonuçları ile uyumlu olduğu görülmektedir.

Ölçek alt boyutlarına göre, katılımcıların cinsiyet, yaş, bulundukları sınıf ve mezun oldukları okul değişkenleri kapsamında elde edilen ortalamalara göre istatistiksel olarak anlamlı bir fark görülmemiştir. Bu sonuç, Şahin ve Kıran (2009) tarafından Çanakkale Onsekiz Mart Üniversitesi Eğitim Fakültesi'nin beş farklı Anabilim Dalında öğrenim görmekte olan 1., 2. ve 3. sınıf öğrencileri ile yapmış oldukları çalışmada elde edilen bulguların bir kısmı ile örtüşmektedir. Yine, Azer'in (2019) özel yetenekli öğrencilerin, görsel okuryazarlık yeterlilikleri üzerine yapmış olduğu çalışmanın toplam puanlarının, cinsiyet ve sınıf değişkenleri açısından anlamlı bir fark ortaya koymadığı görülmüştür. Taşpınar (2017) tarafından görsel sanatlar öğretmeni adaylarının görsel okuryazarlık düzeylerinin belirlenmesi için yapılmış olan başka bir çalışma sonucunda, yine cinsiyet açısından anlamlı bir fark saptanmamıştır ve elde edilen veriler bu bölümde bahsedilen bulguyla benzeşmektedir. Kıran (2008) tarafından yapılmış olan yüksek lisans tezi araştırma sonuçlarına göre ise, beşinci sınıf öğretmen ve öğrencilerinin görsel okuryazarlıkları yeterli düzeydedir ve elde edilen verilere göre, katılımcıların belli boyutlarda cinsiyet ve mezun oldukları okul türlerine göre anlamlı fark göstermedikleri sonucu elde edilmiştir.

Verilen tüm cevaplar değerlendirildiğinde, hiçbir alt boyutta istatistiksel olarak anlamlı bir fark olmamasına rağmen, sadece beşinci alt boyut (Araçlar kullanarak görsel üretebilme) puanlarının ortalamasına göre, kız katılımcılar lehine bir sonuç gözlemlenmiş olduğu söylenebilir. Bu sonuca benzer şekilde, üçüncü araştırma sorusunun, beşinci alt boyut puanlarının ortalamasına göre yinede kız katılımcılar lehine bir sonuç ortaya çıkmış olduğu ifade edilebilir. Bu sonucu destekleyen bir çalışma bulgularına göre ise, ortaokul öğrencilerinin görsel matematik okuryazarlığı algıları, 
kı öğrencilerin lehine anlamlı bir fark ortaya koymuştur (Deveci ve Karademir, 2018).

Çalışmanın bazı sınırlılıkları da mevcuttur. Örneğin, çalışma sadece bir devlet üniversitesinin tek bir anabilim dalında ve yalnızca 3. ve 4. sinıf öğrencilerinin katılımıyla yapılmıştır. Çalışmaya sadece Türk öğrenciler katılmıştır. Özel üniversitelerden katılımcı alınmamıştır. Veriler sadece nicel veri toplama aracı kullanılarak elde edilmiş olup, nitel veri toplama araçlarına yer verilmemiştir.

Çalışmadan elde edilen veriler doğrultusunda şu önerilerde bulunulabilir. Yapılacak benzer çalışmalarda 1. ve 2. sınıf öğrencilerine de yer verilebilir ve ayrıca başka anabilim dallarındaki öğrencilerin de katılımı sağlanabilir. Farklı sınıf düzeylerinden daha fazla sayıda katılımcıya yer verilebilir. Araştırma yapılacak üniversite sayısının artırılması ve özel üniversitelerdeki öğrencilerin de çalışmaya eklenmesi ile farklı boyutlarda sonuçlar elde edilebilir. Ayrıca, eğer varsa, fakültelerdeki yabancı uyruklu öğrencilerle birlikte çalışma yapılarak, bu öğrencilerden elde edilen bulgular Türk öğrencilerin bulguları ile karşılaştırılabilir. Katılımcıların görsel okuryazarlık düzeyleri, bu çalışmada yer verilen değişkenlerden farklı olarak, başka değişkenler (örneğin, sosyo-ekonomik düzey, akademik başarı puanları, vb.) açısından da incelenebilir.

Üniversitelerin Eğitim Fakültelerinin yabancı diller bölümlerinde görsel okuryazarlık konulu dersler verilebilir ya da bu alanla ilgili dersler varsa bu derslerin sayıları artırılabilir. Öğretim elemanları derslerinde görsel materyal kullanımı konusunda bilgilendirilebilir ve daha fazla kullanmaları yönünde teşvik edilebilirler. Öğretim görevlilerine, öğretmen adaylarına ve öğrencilere görsel okuryazarlık eğitiminin nasıl verilmesi gerektiği anlatılabilir. Uygulama sonucu elde edilen kazanımın zaman içinde nasıl ölçüleceği yönünde çalışmalar yapılabilir. 


\section{EXTENDED ABSTRACT}

\section{Determination of the Visual Literacy Levels of Students at the Department of English Language Teaching \\ Müfit Şenel \\ Ondokuz Mayıs University}

The phenomenon of visual literacy, which can be defined as the ability to make visual messages meaningful and similarly create messages, also has an important place in improving the quality and quantity of the learning and teaching process. The fact that visual elements are found in most skills related to foreign language education is known by everyone. For example, visual materials such as pictures, drawings, concept maps and tables are used in almost any environment and source as a part of the foreign language learning and teaching processes. Therefore, to improve students' visual literacy skills is an important subject for their foreign language achievements.

Recently, rapid developments in scientific and technological fields have begun to affect and change the characteristics of people, lifestyles, communication habits and even the values of societies. Accordingly, the concept of literacy expanded and moved to a different dimension, in short, it was not limited to just reading and writing, but also began to be based on visuality and visual knowledge.

It is possible to find many explanations and definitions about visual literacy in the literature. One of these is defined by Heinich, Molenda and Russell in 1989 as visual literacy is "making sense of visual messages and similarly creating messages". In another definition, Wileman (1993) expresses visual literacy as "being able to read and understand graphically and pictorial information". Petterson (1993) defines visual literacy as a process. This process has also been expressed as "a process in which knowledge, behavior and remarkable abilities can be learned and taught and to increase communication skills in different visual forms" (p.135). 
According to Pettersson (1993), for children visual information is more important than verbal information. In addition, visual learning is a preferred learning style not only by children but also by many people, because while only $10 \%$ learning is achieved through listening, this rate rises to $80 \%$ in visual learning. Moreover, while we can remember only $20 \%$ of what we hear, this rate goes above $50 \%$ both in what we see and hear (Heinich et al., 1989). Therefore, since it was thought that students with visual literacy skills could better understand the messages underlying the visuals presented to them in their lessons (Şahin et al., 2013), a visual literacy type was needed to understand and explain the visuals (Göçer and Tabak, 2013).

When the related literature has been searched, there is no study investigating the visual literacy levels of the students of the English Language Teaching Departments reveals the need for work in this area. Additionally, since this study examines the visual literacy levels of the ELT students in terms of various variables, it is important in terms of the contribution it will make to the field, since there has not been a study to investigate the visual literacy levels of the students of the English language teaching department in the literature.

In this study, the following questions were sought to investigate the visual literacy levels of the 3rd and 4th grade students of the ELT department in terms of different variables. Is there any significant difference of visual literacy levels of the participants in terms of,

1. their gender?

2. their grades?

3. their age?

4. high schools graduated from?

This is a descriptive study and a quantitative research model has been used. Quantitative studies are statistical analyzes of data that can be expressed numerically, and are studies that aim to reveal the cause-effect relationships between social data.

The population of the study is the Faculty of Education of a state university in the spring semester of 2019-2020, and the sample consists of 3rd $(44.7 \%)$ and 4 th $(55.3 \%)$ grade students majoring at the Department of English Language Education. The fact that the students in these classes took part in the study, the more use of visual materials in their classes, and 
the expectation that they had a certain ability in terms of visual reading and understanding are the result.

As the data collection tool, the "Visual Literacy Competencies Scale" developed by Kiper, Arslan, K carrier and Akgün (2012) was used. The coding of the "Visual Literacy Competencies Scale" is: (1) I definitely cannot, (2) I cannot, (3) I do more or less, (4) I do, and (5) I do it easily, and it is a five-point Likert type scale. The reliability coefficient is given as 0.94 . The scale includes (1-7) 'giving importance to visuality using office software', (8-11) 'defining printed visual materials', (12-16)' visual interpretation ', (17-21)' distinguishing visual messages encountered in daily life. (22-26) 'ability to produce visuals using tools' and (27-29) 'ability to perceive messages in visuals'.

All of the data obtained in the study were analyzed with the SPSS 25 program. In order to determine the analyzes to be used in the study, the result of whether the obtained data is suitable for normal distribution was investigated and it was determined that the data were suitable for normal distribution ( $\mathrm{p}>$.05).

According to the results of the study, when we look at the average of the answers given to the items in the scale for determining the visual literacy levels of the 3rd and 4th grade students of the ELT department participating in the study, it is concluded that the participants have a high level of visual literacy.

According to the sub-dimensions of the scale, no statistically significant difference was found according to the averages obtained within the variables of the participants' gender, age, grades and high schools they graduated from.

When all the responses are evaluated, it can be said that although there is no statistically significant difference in any sub-dimension of the scale, a result in favor of female participants was observed only according to the average scores of the fifth sub-dimension (ability to produce visuals using tools). Similar to this result, it can be stated that the third research question still has a result in favor of female participants according to the average of the fifth sub-dimension scores.

Visual literacy courses can be given in the foreign languages departments of the education faculties of universities, or if there are courses in this field, the number of these courses can be increased. Instructors can be 
informed about the use of visual materials in their lessons and they can be encouraged to use more. How visual literacy education should be given to lecturers, teacher candidates and students can be explained.

\section{Kaynakça / References}

Akçam, H. K. (2006). Görsel okumanın ilköğretim 5. sinıf bilgi verici metinlerde anlam kurmaya etkisi. Yayınlanmamış Yüksek Lisans Tezi. Gazi Üniversitesi, Eğitim Bilimleri Enstitüsü, Ankara.

Akaroğlu, E. G. ve Dereli, E. (2012). Okul öncesi çocukların görsel algı eğitimlerine yönelik geliştirilmiş eğitici oyuncakların çocukların görsel alg1larına etkisi. Journal of World of Turks, 4(1), 201-222.

Akyol, H. (2006). Yeni programa uygun Türkçe öğretim yöntemleri. Ankara: Kök Yayıncilik.

Akpınar, B. (2009). İlköğretim 1-5. sınıflar Türkçe öğretim programları görsel okuma ve sunu öğrenme alanının değerlendirilmesi. Eğitim ve Bilim, $34(154), 37-49$.

Alpan, G. (2008). Görsel okuryazarlık ve öğretim teknolojisi. Yüzüncü Yıl Üniversitesi Ĕ̆itim Fakültesi Dergisi, 5(2), 74-102.

Anderson, E., (2002). Enhancing visual literacy through cognitive activities. Proceedings of the 2002 ASEE/SEF/TUB Colloquium, Carnegie Mellon University: American Society for Engineering Education.

Arıkök, İ. (2001). Beş-altı yaş çocuklarında görsel algı eğitiminin okuma olgunluğuna olan etkisinin incelenmesi. Yayınlanmamış Yüksek Lisans Tezi. Gazi Üniversitesi, SBE Dergisi ,Ankara.

Avgerinou, M. and Ericson, J. (1997). A review of the concept of visual literacy. British Journal of Educational Technology, 28, 280-91.

Azar, A., Presley, İ.A. ve Balkaya, Ö. (2006). Çoklu zeka kuramına dayalı öğretimin öğrencilerin başarı, tutum, hatırlama ve bilişsel süreç becerilerine etkisi. H.Ü. Eğitim Fakültesi Dergisi (H.U. Journal of Education). 30, 45-54.

Azer, Y. (2019). Özel yetenekli öğrenciler ve akranlarının görsel okuryazarlık düzeyleri ve Fen Dersindeki görselliğe ilişkin görüşleri. Yayınlanmamış Yüksek Lisans Tezi Sakarya Üniversitesi, Eğitim Bilimleri Enstitüsü, Sakarya. 
Balun, H. (2008). İlköğretim I. kademede uygulanan görsel okuma ve görsel sunu öğrenme alanının Türkçe öğretiminde kazanımlara ulaşmadaki etkililiği (Bingöl-Elazı̆̆-Diyarbakır örnĕ̆i). Yayınlanmamış Yüksek Lisans Tezi. Firat Üniversitesi, $S B E$,Elazığ.

Bangir, G. A. (2008). Görsel okuryazarlık ve öğretim teknolojisi. Yüzüncü Yıl Üniversitesi, Ĕ̆itim Fakültesi Dergisi, 5(2), 74-102.

Braden, R. A. (1996). Visual literacy. In D. H. Jonassen (Ed.), Handbook of Research for Educational Communications and Technology (p.491-520). New York: Simon \& Schuster.

Büyüköztürk, Ş., Akgün, Ö. ve Karadeniz, Ş. (2010). Bilimsel Araştırma Yöntemleri. Ankara: Pegem Yay.

Cengiz, Ö. (2002). 5-6 yaş çocuklarının görsel algı gelişimini destekleyici eğitim programının etkisi. Yayınlanmamış Yüksek Lisans Tezi. Marmara Üniversitesi, Eğitim Fakültesi, İstanbul.

Çam, B. (2006). İlköğretim öğrencilerinin görsel okuma düzeyleri ile okudŭ̆unu anlama, eleştirel okuma ve Türkçe dersi akademik başarıları arasındaki ilişki. YayınlanmamışYüksek Lisans Tezi. Eskişehir Osmangazi Üniversitesi, SBE, Eskişehir.

Chauvin, B. A. (2003). Visual or media literacy? Journal of Visual Literacy, 23(2), 119-128.

Demir, R. ve Aybek, B. (2012). Dokuzuncu sınıf öğrencilerinin öğrenme stilleri ve çoklu zeka alanlarının incelenmesi. Uluslararası Ĕ̆itim Programları ve Öğretim Çalışmaları Dergisi, 3, 27-40.

Demirci, A. (2010). Görsel algı eğitiminin beş-altı yaş çocuklarının görsel algı gelişimlerine etkisi. Yayınlanmamış Doktora Tezi. Gazi Üniversitesi, Eğitim Bilimleri Enstitüsü, Ankara.

Deveci, Ö. ve Karademir, Ç.A. (2018). Ortaokul öğrencilerinin matematik özbildirimleri ile görsel matematik okuryazarlığı öz-yeterlik algıları. Ĕ̆itim Kuram ve Uygulama Araştırmaları Dergisi, 4(3), 33-49.

Duran, M. (2013). İlköğretim 7. sınıf öğrencilerinin görsel matematik okuryazarlığı hakkındaki görüşleri. Mehmet Akif Ersoy Üniversitesi Ĕ̆itim Bilimleri Enstitüsü Dergisi, 2(2), 38-51.

Erdem, M. (2006). Anaokuluna devam eden beş-altı yaş çocuklarının matematiksel becerileri ile görsel algı becerilerinin karşılaştırılması. Yayınlanmamış Yüksek Lisans Tezi. Hacettepe Üniversitesi, SBE, Ankara. 
Erem, H. Ö. ve Kırkkılıç, H. A. (2015). Türkçe eğitimi bölümü 4. sınıf öğrencilerinin görsel okuryazarlık yeterliliklerinin öğrenim türlerine göre incelenmesi. Erzincan Üniversitesi Sosyal Bilimler Enstitüsü Dergisi, 2, 285290.

Felten, P. (2008). Visual literacy. Change, 40(6), 60-64.

Fox, D. (1969). The research process in education. Holt: Rinehart.

Göçer, A. ve Tabak, G. (2013). Öğretmen adaylarının görsel okuryazarlıkla ilgili algıları. Adıyaman Üniversitesi Sosyal Bilimler Enstitüsü Dergisi, 6(11), 518-541.

Güneş, F. (2016). Kağıttan ekrana okuma alanındaki gelişmeler. Bartın Üniversitesi Ĕ̆itim Fakültesi Dergisi, 5(1), 1-18.

Heinich, R., Molenda, M. and Russel, J. D. (1989). Instructional media and new technologies of instruction (Third Edition). Macmillan Publishing Company.

Huilcapi-Collantes, C., Hernandez, A and Hernandez-Ramos, J.P. (2020). The effect of a blended learning course of visual literacy for in-service teachers. Journal of Information Technology Education, 19, 131-166.

İşler, A. Ş. (2002). Günümüzde görsel okuryazarlık ve görsel okur yazarlık eğitimi. Uludağ Üniversitesi Ĕ̆itim Fakültesi Dergisi, 15(1), 153-161.

Kalaycı, Ş. (2014). SPSS uygulamalı çok değişkenli istatistik teknikleri (6. Basım). Ankara: Asil Yayın Dağıtım.

Karasar, N. (2005). Bilimsel araştırma yöntemleri. (15. baskı). Ankara: Nobel Yayın Dağıtım.

Kaya, M. F. (2011). Öğrencilerde görsel okuryazarlık becerilerinin geliştirilmesine yönelik coğrafya öğretmenlerinin görüş ve uygulamaları. Turkish Studies, 6(2), 631-644.

Kıran, I. (2008). Ilköğretim 5. sinıföğretmen ve öğrencilerinin görsel okuryazarlıkları üzerine bir araştırma. Yayımlanmamış Yüksek Lisans Tezi. Çanakkale Onsekiz Mart Üniversitesi, SBE, Çanakkale.

Kiper, A., Arslan, S., Kıyıcı, M. ve Akgün, Ö.E. (2002). Visual literacy scale: The study of validity and reliability. TOJNED,2(2), 73-83.

Kiper, A., Kırksekiz, A. ve Çam, E. (2014). Üniversite öğrencileri görsel okuryazarlık düzeyleri. Instructional Technologies \& Teacher Education Symposium, Afyonkarahisar, s.56-61.

Kocaarslan, M. ve Çeliktürk, Z. (2013). Eğitim fakültesi öğrencilerinin görsel okuryazarlık yeterliklerinin belirlenmesi. Bartın Üniversitesi Ĕ̆itim Fakültesi Dergisi, 2(2), 344-362. 
MEB (2018). İlköğretim kurumları (2.-8. sınıflar) ingilizce dersi öğretim programı. Ankara: MEB Yay.

MEB (2018). Ortaöğretim ingilizce dersi (9. ve 12. sinuflar) öğretim programı. Ankara: MEB Yay.

Mert, E.L. (2017). 6. ve 8. sınıf öğrencilerinin görsel okuryazarlık yeterlilikleri. International Journal of Languages' Education and Teaching, 5(1), 255-266.

Moline, S. (2012). I see what you mean. Stenhouse Publishers.

Örs, E. ve Baş, B. (2018). İkinci sınıf öğrencilerinin görsel okuryazarlığı üzerine bir araştırma. Ana Dili Ĕ̆itimi Dergisi, 6(1), 95-113.

Özdemir, A. Ş. ve Yıldız, S. G. (2015). Yedinci sınıf öğrencilerinin görsel okuryazarlık düzeylerinin incelenmesi. International Journal of Social Science, 41, 529-541. http://dx.doi.org/10.9761/JASSS3204

Petterson, R. (1993). Visual information, Educational Technology. Englewood: Cliffs.

Pettersson, R. (2012). Information design 3. image design. Tullinge: Sweden. Institute for Infology.

Reinking, D., Mckenna, M.C., Labbo, L.D. and Kieffer, R.D. (Eds.). (1998). Handbook of technology and literacy: Transformations in a post-typographic world. Mahwah, NJ: Erlbaum.

Roth, W. M., Bowen, G. M. and Mcginn, K. M. (1999). Differences in graphrelated practices between high school biology textbook and scientific ecology journals. Journal of Research in Science Teaching, 36(9), 9771019.

Sims, E., O'leary, R., Cook, J. and Butland, G., (2002). Visual literacy: What is it and do we need it to use learning technologies effectively? Proceedings of the Annual ASCILITE Conference on December 1-6,Aucland: New Zealand.

Suryanto, S. (2014). How can visual literacy support english language teaching? LINGUA, Jurnal Bahasa \& Sastra, 15(1), 35-43.

Şahin, Ç. ve Kıran, I. (2015). Öğretmen adaylarının algılarına göre görsel okuryazarlık düzeylerinin değerlendirilmesi. Dumlupınar Üniversitesi Sosyal Bilimler Dergisi, 23, 77-90.

Şahin, Ç., Kurudayıŏ̆lu, M. ve Çelik. G. (2013). Türkçe öğretmeni adaylarının görsel okuryazarlıkları üzerine bir araştırma. Ana Dili Ĕ̆gitim Dergisi, 1(1), 129-143. 
Taşpınar, Ş. E. (2017). Görsel sanatlar öğretmeni adaylarının görsel okuryazarlık düzeylerinin belirlenmesi. Erzincan Üniversitesi Eğitim Fakültesi Dergisi, 19(2), 321-334.

Temizkan, M. ve Ünlüoğlu, C. (2017). Görsel destekli yazma etkinliklerinin öğrencilerin yazma başarılarına ve yazmaya yönelik görüşlerine etkisi. Dicle Üniversitesi Ziya Gökalp Ĕ̆itim Fakültesi Dergisi, 30, 437-448.

Tukey, J. (1949). One degree of freedom test for non-additivity. Biometrics, 5, 232-242.

Uzun, Y. ve Çelik, G. (2020). Akademisyenlerin okuryazarlık algısındaki değişimler. OPUS Uluslarası Toplum Araştırmaları Dergisi, 15(2), 11341156. https://doi.org/10.26466/opus.646592

Wileman, R. E. (1993). Visual communicating. Englewood Cliffs, N. J.: Educational Technology Publications.

Yeh, H. T. (2008). Visual literacy: An investigation of how pre-service teachers interpret and analyze instructional visual materials. Unpublished doctoral dissertation. University of Northern Colorado.

Zeren, G. ve Arslan, R. (2009). Bir eğitim süreci olarak görsel okuryazarlık. Türkiye Sosyal Araştırmalar Dergisi, 3, 43-52.

MEB, (2018, Mayıs). MEB IYS dosyalar: Çoklu zeka ölçüm testi. Erişim adresi: http://www.meb.k12.tr/meb iys dosyalar/58/01/198697/dosyalar/2014 02/22125116 coklu zeka olcum testi 1.doc

\section{Kaynakça Bilgisi / Citation Information}

Şenel, M. (2021). İngiliz Dili Eğitimi Anabilim Dalı öğrencilerinin görsel okuryazarlık düzeylerinin analizi. OPUS-Uluslararası Toplum Araştırmaları Dergisi, 18(Eğitim Bilimleri Özel Sayıs1), 4126-4150. DOI: 10.26466/opus. 922770. 